\title{
UDC 629.463.65.015:625.1.032
}

\section{A. O. SHVETS ${ }^{1 *}$, O. O. BOLOTOV ${ }^{2 *}$}

1*Dep. «Theoretical and Structural Mechanics», Dnipro National University of Railway Transport named after Academician V. Lazaryan, Lazaryan St., 2, Dnipro, Ukraine, 49010, tel. +38 (050) 21414 19, e-mail angela_Shvets@ua.fm, ORCID 0000-0002-5537-6617

${ }^{2 *}$ BRL DSRS, Dnipro National University of Railway Transport named after Academician V. Lazaryan, Lazaryan St., 2, Dnipro, Ukraine, 49010, tel. +38 (097) 97757 08, e-mail bolaks@i.ua, ORCID 0000-0002-0807-0340

\section{INFLUENCE OF LOADING FROM THE AXLE OF A GONDOLA CAR ON ITS DYNAMIC INDICATORS AND RAILWAY TRACK}

Purpose. Increasing the maximum loading from the car axle on the rails during transportation of goods and the speed of movement of railway vehicles will enhance the integration processes between the countries. In order to ensure safe and reliable traffic at the railways it is necessary to improve control, quantitative evaluation of the dynamic loading of the rolling stock, which in the process of its operation is a relevant scientific and technical problem. The purpose of this work is to study the influence of the axle loading increase in gondola cars, taking into account the possible speed increase on their main dynamic indicators and indicators of interaction of rolling stock and track. Methodology. The study was carried out by the method of mathematical and computer simulation of the dynamic loading of a gondola car using the model of spatial oscillations of the coupling of five cars and the software complex developed in the branch research laboratory of the dynamics and strength of rolling stock (BRL DSRS). The initial data for research are as follows: the movement of gondola car of the model 12-532 with typical bogies of $18-100$ at the speeds ranging from 50 to $90 \mathrm{~km} / \mathrm{h}$ in curves with radii of 350 and $600 \mathrm{~m}$, with superelevation of 130 and $120 \mathrm{~mm}$, respectively. Findings. The article analyzes the dynamic qualities of a rolling stock using the example of gondola cars, the calculations are performed using the package of applied programs with sufficient accuracy for practice. During the theoretical studies and simulation, taking into account the processes of freight car oscillation in case of increasing the axle loading, the dependences of the main dynamic parameters, taking into account the movement speed were obtained. Originality. Originality of the work results lies in the study of the influence of increasing the axle loading in gondola cars, taking into account the possible movement speed increase on the dynamic loading in order to solve the problem of forecasting the rolling stock dynamics. The results of theoretical studies, taking into account the movement speed in the curved track sections of small and medium radius were obtained for the first time. Practical value. The application of these results will contribute to improving the traffic safety of freight cars and will improve the technical and economic performance of railway transport.

Keywords: cargo; gondola cars; dynamic indicators; curved track sections; axle loading; interaction indicators; rolling stock and track; gravity center; movement speed

\section{Introduction}

In accordance with the established rules of loading, placing and fastening of cargoes in cars should ensure: movement and operation safety of railway transport; possibility of mechanization of loading and unloading works; preservation of goods and cars.

In addition, one of the main indicators of the efficiency of the car fleet operation is the duration of the loading and unloading operations, which depends on the fitting of freight points at the railway stations and industrial enterprises with modern means of mechanization. The planned reduction of the freight car turnover in 2017-2021, taking into account the improvement of the operation and renovation of the car fleet, is presented in Fig. 1 [3].

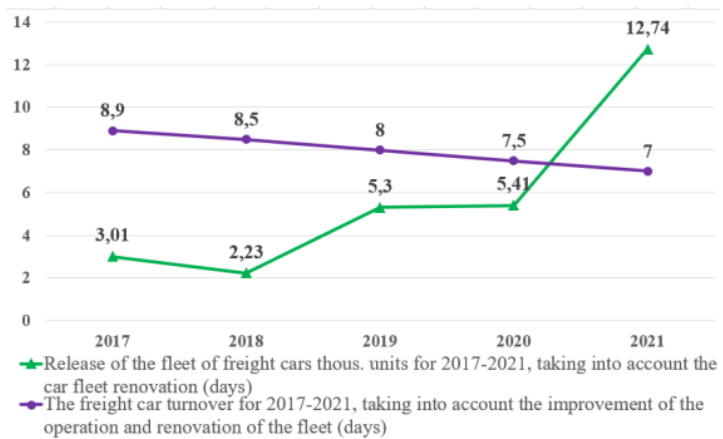

Fig. 1. Reduction of the freight car turnover 
Due to the introduction of new equipment for loading and unloading operations, it is possible to reduce the level of car idle and to minimize it in future (Fig. 2).

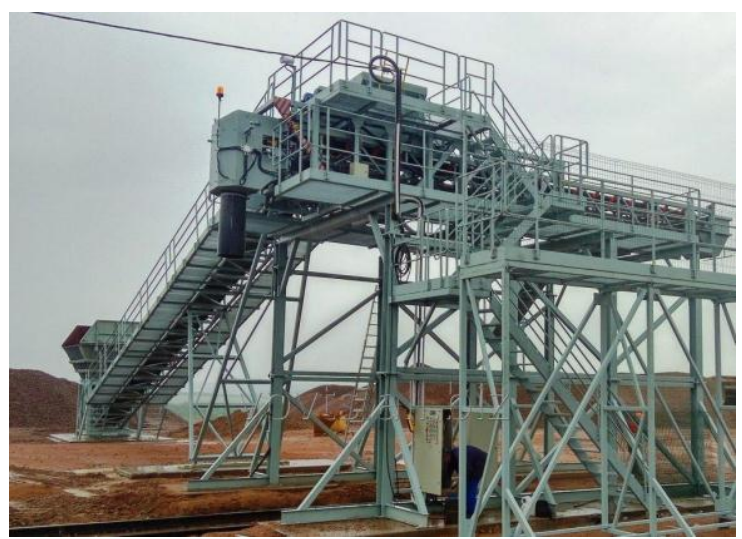

Fig. 2. Automated system of the dose loading of broken stone in cars

For example, the automated system of dose loading of broken stone in cars provides [1]:

$a$

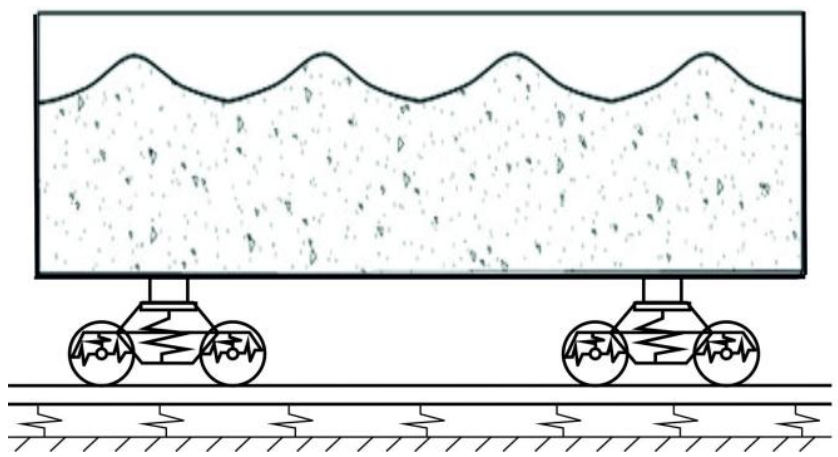

- dose loading of railway cars;

- uniform loading of cars along the length;

- the exclusion of time and labor costs arising from inadequate loading of cars;

- automated shipping accounting with print output of information and automated control system of enterprise.

Safety performance during transportation of bulk cargo of open storage in accordance with the requirements of the Rules for the transportation of bulk cargo and the Rules for the transportation of goods in open cars remains the main task of the transport industry enterprises. As it is known, depending on the method of loading the gondola cars with bulk cargo, the form of cargo inequalities may be different (Fig. 3). In accordance with clause 5 of the Rules for the transportation of goods in open cars, one should in all cases level the cargo surface $[9,12,13]$.

Fig. 3. The form of cargo inequality:

$a$ - longitudinal; $b$ - transverse

In order to level the cargo, the most often nonmechanized method is used, which affects the idle increase of gondola cars under freight operations, as well as increase of the total transportation cost. In addition, manual leveling can lead to accidents involving the risk of person`s falling from height.

The leveling construction (Fig. 4) should allow the leveling of the bulk cargo, regardless of the form of its position in the gondola car. The proposed designs of rotary and screw device for the mechanization of bulk cargo leveling in gondola cars have no analogues in domestic and world practice [9]. $b$

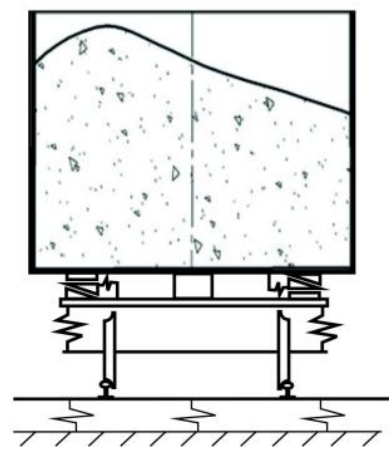

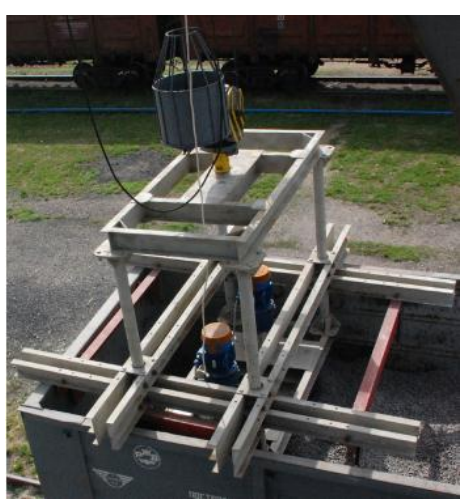

Fig. 4. The device for bulk cargo leveling in gondola cars of the UkrDURT system 
Each of them has its advantages and disadvantages, namely:

- rotary leveler has a lower mass and a significantly lower cost, but it can only work with cargoes of relatively small bulk density and satisfactory flowability;

- screw leveler, which has greater material consumption and price, makes it possible to mechanize the leveling of heavy cargoes with bad flowability.

In addition, the loading should be carried out in accordance with the current technical specifications. Determination of the displacement of the load gravity center relative to the railway car symmetry axes using the car scales (Figure 5) allows us to quickly detect dangerous deviations in the car stability and thus significantly increase safety during the train movement [4].

Where it is necessary to reduce the labour intensity, minimize the influence of human factor, reduce the time spent for the inspection of cars, the appropriate solution is to automatically scan and check the contents of cars involving operator only in the case of alarm signals from the control system.

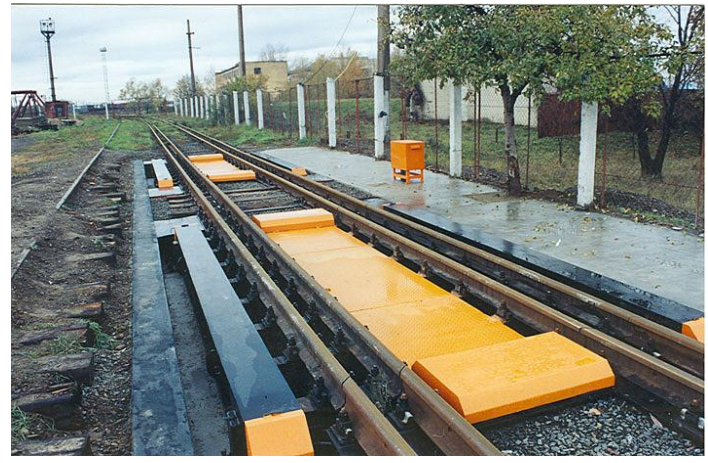

Fig. 5. Computerized car scales for weighing in static mode

The hardware-software complex for controlling the car loading is intended for automatic 3D scanning of gondola cars when moving in order to evaluate the level of car volume loading, the uniformity of cargo distribution, cargo volume, detect foreign objects, as well as for other functions in the interests of production services, logistics and safety (Fig. 6) [2].

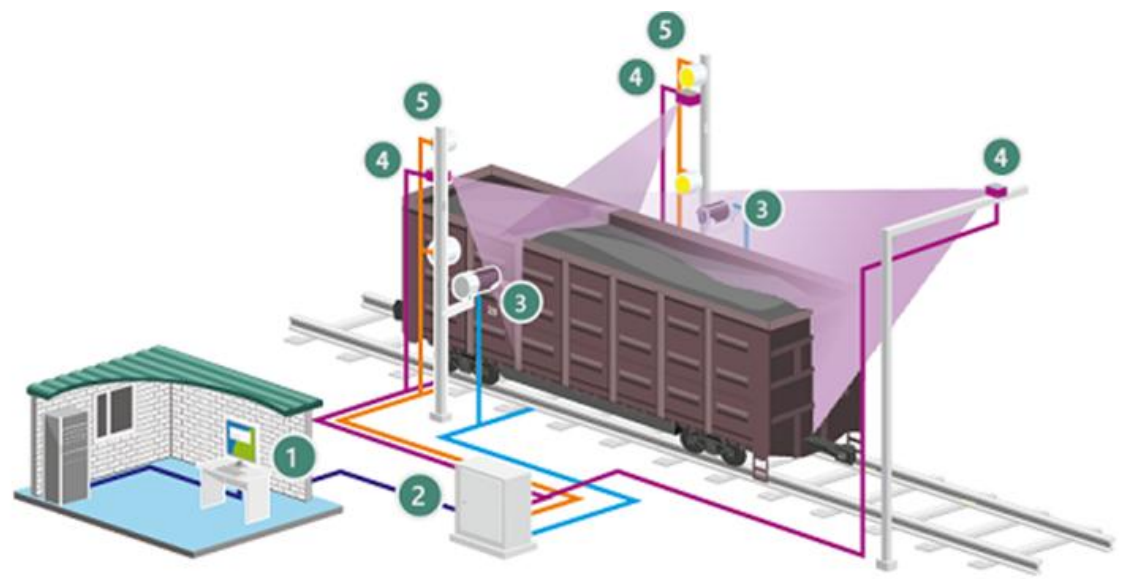

Fig. 6. Hardware-software complex for controlling the car loading:

1 - computer with ARSCIS.Scanner software; 2 -ARSCIS.Scanner box; 3 - video cameras for detection; 4 - scanner of dimensions; 5 - spotlights

Automation of visual control of the car contents provides:

- reducing the time and labor cost for car control operations;

- minimization of human factor influence;

- safety improvement of the railway freight transportations;
- reduction of losses due to underloading/overloading of cars;

- products thievery prevention by railway transport.

The main functions of the hardware and software complex are as follows: 
- car and cargo scanning using industrial laser sensors;

- construction of a three-dimensional model of the car (and its contents) and its analysis;

- determining the level of car loading;

- detection of foreign objects in an empty car;

- control of the distribution evenness of bulk cargo in a car;

- cargo volume evaluation in a car;

- detection of loading errors (overloading, underloading, unevenness).

The leading domestic developer of unloading systems for unloading bulk cargoes from the railway transport and the largest producer of technological equipment, which is the part of unloading complexes, is Dniprovazhmash PJSC (Fig. 7) [15].

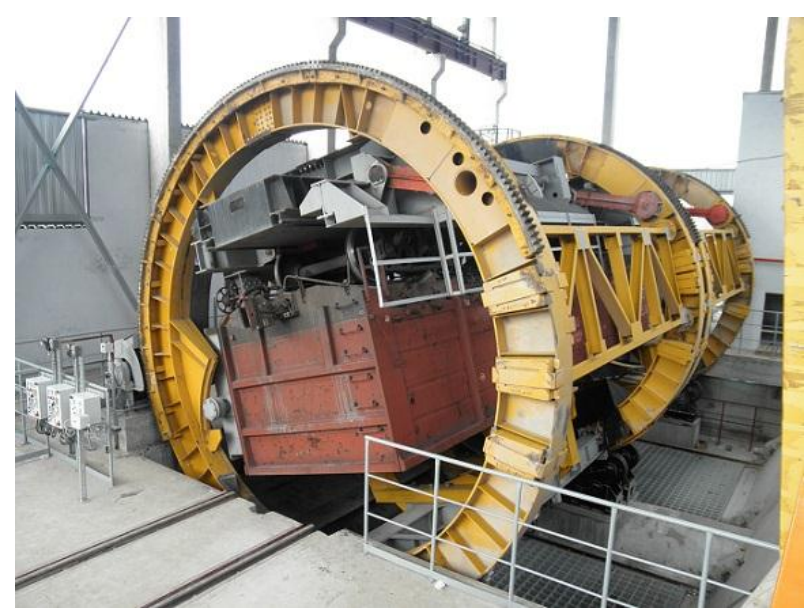

Fig. 7. Stationary rotary car dumper VRS-93, VRS-93-110

Stationary rotary car dumpers, which are produced by Dniprovazhmash PJSC, are intended for unloading of gondola cars with bulk cargo with carrying capacity $60 \div 110$ t by means of gondola cars overturning in a rotary car dumper.

Composite application of modern innovative technologies in railway transport will allow the preservation of cars, reducing their idle time, releasing a significant number of workers from heavy manual operations and obtaining significant economic benefits.

\section{Purpose}

The State Administration of Railway Transport of Ukraine established the maximum loading from the car axle on the rails when transporting the freights destinated to individual European countries and border crossings along the track $1520 \mathrm{~mm}$ from 20 to 24.5 tons by the telegram dated November 7, 2011, No. CZM-12/2074 according to the Minutes of the meetings on the harmonization of the volumes of the transportation conditions.

Increasing the permissible loading on the car axle, with simultaneous increase in the speed of the railway vehicles, will strengthen the integration processes with the countries of Europe and Asia. The application of modern railway innovative technologies described above makes it possible to increase axle loading, but leads to the need for improved control, quantitative evaluation of the dynamic loading of rolling stock to ensure safe and reliable connection at the railways.

The limit axle loading for freight cars of 23.5 tons per axle was taken into account as one of the main prerequisites for determining the permissible speeds of rolling stock, the order and terms for the designation of repair and track works and labor standards for maintenance of the track and artificial structures. Increasing the axle loading, in turn, leads to the failure rate increase of the rails due to defects of contact-fatigue nature and the deterioration of the track condition. Therefore, in the design process of rolling stock quantitative evaluation of dynamic loadings is a relevant scientific and technical problem [5, 14, 18-22].

The article is aimed to study the influence of increasing the axle loading in gondola cars, taking into account the possible increase in the movement speed on their main dynamic indicators and interaction indicators of track and rolling stock.

\section{Methodology}

During operation of trains, primarily the ones with increased length and weight, particular attention is paid to the evaluation of the dynamic performance of vehicles, among which the most important is the indicator characterizing the traffic safety of a vehicle - the stability coefficient against derailment. For this purpose, the mathematical models of spatial oscillations of the car (or group of cars) moving in a train are used.

The models of rolling stock, as a rule, represent the variations of the system of differential equations in the second-order partial derivatives compiled according to the Lagrange-d'Alembert prin- 
ciple, which correspond to the set task. Using such models, the problem can be found analytically. Mathematical modeling makes it possible to determine the dynamic parameters of cars during their movement in straight and curved track sections with real irregularities in the vertical and horizontal planes, taking into account the actual wheel thread and the rail head profile $[6,11,16,17]$.

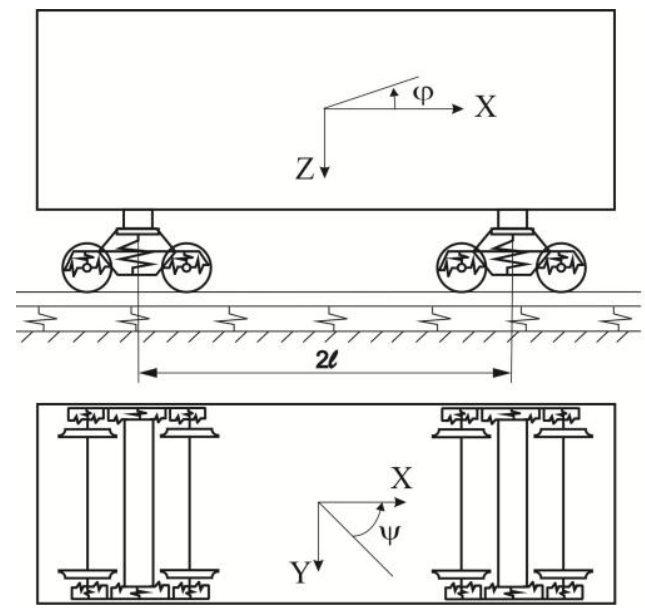

Fig. 8. Calculation scheme of 4-axle gondola car

Table 1

System bodies and their displacements

\begin{tabular}{|c|c|c|c|c|c|c|}
\hline \multirow{3}{*}{ System bodies } & \multicolumn{6}{|c|}{ Displacement } \\
\hline & \multicolumn{3}{|c|}{ Linear along the axes } & \multicolumn{3}{|c|}{ Angle along the axes } \\
\hline & $\mathrm{X}$ & $\mathrm{Y}$ & $Z$ & $\mathrm{X}$ & $\mathrm{Y}$ & $Z$ \\
\hline Body & $x$ & $y$ & $z$ & $\theta$ & $\varphi$ & $\psi$ \\
\hline Bolsters & $x_{\mathrm{i}}$ & $y_{\mathrm{i}}$ & $z_{\mathrm{i}}$ & $\theta_{\mathrm{i}}$ & $\varphi_{\mathrm{i}}$ & $\psi_{\mathrm{i}}$ \\
\hline Side frames & $x_{\mathrm{sij}}$ & $y_{\mathrm{sij}}$ & $z_{\mathrm{sij}}$ & $\theta_{\mathrm{sij}}$ & $\varphi_{\mathrm{sij}}$ & $\psi_{\mathrm{sij}}$ \\
\hline Wheel sets & $x_{\text {kim }}$ & $y_{\text {kim }}$ & $z_{\text {kim }}$ & $\theta_{\text {kim }}$ & $\varphi_{\text {kim }}$ & $\psi_{\text {kim }}$ \\
\hline Rails & - & $y_{\text {pimj }}$ & $z_{\text {pimj }}$ & - & - & - \\
\hline
\end{tabular}

In Table 1 the displacements of the gravity center of the body along the corresponding axes are indicated by $x, y$ and $z$, and rotation angles of the body relative to the main central inertia axes by $\theta, \varphi, \psi$. Similar bolster displacements are provided by the index i ( $i=1,2$ bogie number), side frames - by the index sij $(. j=1 .-$ left, $j=2$ right side of a car), wheel sets - by the index kim
The oscillations of a single car and its interaction with the rail track are considered using quite full calculation schemes. Fig. 8 shows the calculation scheme of the freight car and shows positive directions for all displacements and rotation angles, and the designation of the system bodies are given in Table 1.

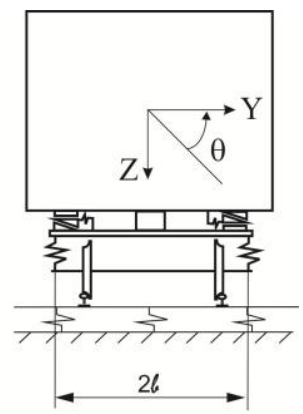

$(\mathrm{m}=1,2$ - number of wheel set in a bogie), rails at the contact points with the wheels pimj (rail displacements are provided only in two directions along the axes $\mathrm{Y}$ and $\mathrm{Y}$ ). Displacements of the wheels are indicated by the index imj .

The work [6] proposes a mathematical model describing the spatial oscillations of the car coupling in a train (Fig. 2), one rail carriage of which 
is considered according to the fullest calculation scheme (called "zero"), and the calculation schemes of neighboring cars, depending on the task setting, are simplified as further is the distance from the "zero" carriage on both sides.

A mechanical system with 58 degrees of freedom is taken as a calculation scheme of the "zero" carriage. The following values are taken as generalized coordinates: $q_{1}=z, q_{2}=\varphi, q_{3}=\theta, q_{4}=y$, $q_{5}=\psi, \quad q_{\mathrm{n}}=\theta_{\mathrm{i}} \quad(n=6,7), \quad q_{\mathrm{n}}=\psi_{\mathrm{i}} \quad(\mathrm{n}=8,9)$, $q_{\mathrm{n}}=\psi_{\mathrm{sij}} \quad(n=10 \div 13), \quad q_{\mathrm{n}}=y_{\mathrm{sij}} \quad(n=14 \div 17)$,

$$
\begin{array}{llll}
q_{\mathrm{n}}=z_{\mathrm{sij}} & (n=18 \div 21), & q_{\mathrm{n}}=\varphi_{\mathrm{sij}} & (n=22 \div 25), \\
q_{\mathrm{n}}=\psi_{\text {kim }} \quad(n=26 \div 29), & q_{\mathrm{n}}=y_{\text {kim }} & (n=30 \div 33), \\
q_{\mathrm{n}}=z_{\text {kim }} \quad(n=34 \div 37), & q_{\mathrm{n}}=\theta_{\text {kim }} & (n=38 \div 41), \\
q_{\mathrm{n}}=y_{\text {pimj }} \quad(n=42 \div 49), & q_{\mathrm{n}}=x_{\mathrm{sij}} & (n=50 \div 53), \\
q_{\mathrm{n}}=x_{\text {kim }} \quad(n=54 \div 57), & q_{58}=x . &
\end{array}
$$

The cars, adjacent to the "zero" one, are represented by a system with 12 degrees of freedom. In the calculation schemes describing the oscillations of these cars, the main features of freight car bogies are preserved - the side frames lozenging.
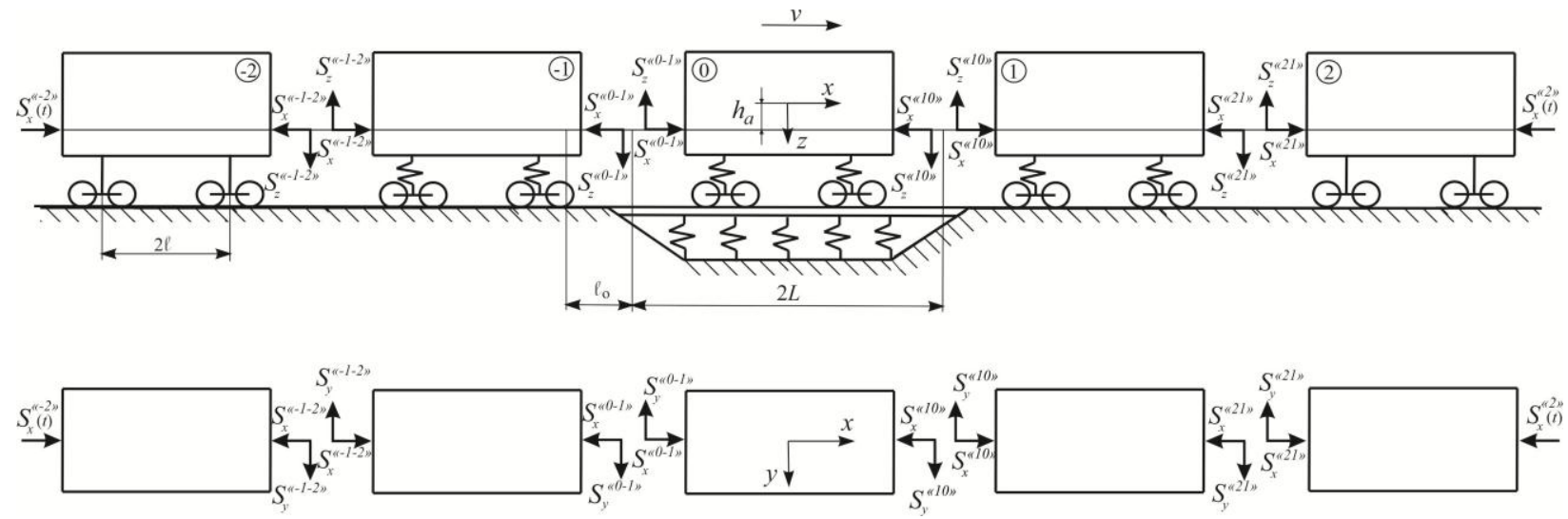

Fig. 9. The forces arising from the action of longitudinal forces in the auto-couplings of cars

During the study of spatial oscillations of cars adjacent to the "zero" one, considered by the simplified calculation scheme, the following assumptions are introduced. It is assumed that the cars have single-stage spring suspension. Each of them consists of eleven solid bodies: a body, two bolsters, four side frames of the bogie and four wheel sets. Unlike "zero" car, the track under adjacent cars is considered to be absolutely rigid in the vertical direction and elastic in the horizontal transverse direction. This assumption does not lead to increase in the number of degrees of freedom, since the speed of rails displacement in the expressions for transverse forces can be neglected.

The following values are taken as the generalized coordinates for these cars: $q_{1}^{n}=z^{n}, q_{2}^{n}=\varphi^{n}$, $q_{3}^{n}=\theta^{n}, \quad q_{4}^{n}=y^{n}, \quad q_{5}^{n}=\psi^{n}, \quad q_{\mathrm{k}}^{n}=\psi_{\mathrm{i}}^{n} \quad(\mathrm{k}=6,7)$, $q_{\mathrm{k}}^{n}=\psi_{\mathrm{si}}^{n} \quad(\mathrm{k}=8,9), \quad q_{\mathrm{k}}^{n}=y_{\mathrm{si}}^{n} \quad(\mathrm{k}=10,11)$, $q_{12}^{n}=x^{n}$, where $\mathrm{i}=1,2 ; \mathrm{n}=1$ and -1 - for the «first» and «minus first» cars correspondingly.

Outer cars of coupling, which by analogy we call «second» and «minus second», are considered using even more simplified scheme than the «first» and «minus first» cars. In «second» and «minus second» cars we will take into account only oscillations of bodies, that is, these cars are the systems with six degrees of freedom: $q_{1}^{n}=z^{n}, q_{2}^{n}=\varphi^{n}$, $q_{3}^{n}=y^{n}, q_{4}^{n}=\theta^{n}, \quad q_{5}^{n}=\psi^{n}, \quad q_{6}^{n}=x^{n}$,

where $\mathrm{n}=2$ and -2 - for the «second» and «minus second» cars, correspondingly.

As it is known, the traffic safety of trains and preservation of the transported cargoes depend directly on the method of placement and fastening of cargoes. Particular attention is paid to the center of gravity. For stability and safety of transportation, the bulk cargoes in the gondola car bodies should be fully leveled, so that the load on the bogies would be the same and the gravity center is at the 
intersection of the central longitudinal and transverse lines.

The complement of the mathematical models of spatial oscillations by the initial data with the specified inertial characteristics of the car and cargo elements makes it possible to approximate the results of calculations to the real state of objects and thereby increase the objectivity of mathematical and computer simulation $[11,16,17]$.

Different variants of the axle loading of a car in the range from 21.4 tons to 24.5 tons per axle are considered. Initial calculations were made with the axle loading of 21.4 tons per axle. The increase in the axle loading was supposed to be achieved by increasing the load mass in the body, subject to its uniform distribution. In this case, the weight of the cars, the inertia moments $I_{\mathrm{x}}, I_{\mathrm{y}}, I_{\mathrm{z}}$ and the height of the mass center of the body $h$ above the level of rail heads vary. The preparatory calculations using the "Software complex for determining the inertia moments of the car bodies" were carried out. They are given in Table 2 [17].

Inertia and mass characteristics of the gondola car during increased loading from the car axle on the rails

\begin{tabular}{c|c|c|c|c|c|c}
\hline \multirow{2}{*}{$P_{\mathrm{st}}, \mathrm{t}$} & \multirow{2}{*}{$M_{\mathrm{c}}, \mathrm{t}$} & $M_{\mathrm{o}}, \mathrm{t}$ & \multicolumn{3}{|c|}{ Inertia moments, $\mathrm{t} \cdot \mathrm{m}^{2}$} & \multirow{2}{*}{$h, \mathrm{~m}$} \\
\cline { 4 - 6 } & & & $I_{\mathrm{x}}$ & $I_{\mathrm{y}}$ & $I_{\mathrm{z}}$ & \\
\hline 21.4 & 85.6 & 76.5 & 75 & 1050 & 1100 & 1.84 \\
\hline 22.0 & 88.0 & 78.9 & 77.3 & 1082 & 1133 & 1.86 \\
\hline 22.5 & 90.0 & 80.9 & 79.5 & 1113 & 1166 & 1.88 \\
\hline 23.0 & 92.0 & 82.9 & 81.3 & 1138.2 & 1192.4 & 1.9 \\
\hline 23.5 & 94.0 & 84.9 & 83.25 & 1165.5 & 1221 & 1.93 \\
\hline 24.0 & 96.0 & 86.9 & 85.2 & 1192.8 & 1249.6 & 1.97 \\
\hline 24.5 & 98.0 & 88.9 & 87.15 & 1220.1 & 1278.2 & 2.02
\end{tabular}

\section{Findings}

Calculations can be made with sufficient accuracy for practice, limited to consideration of the movement of a group of five cars (Fig. 2). The research was carried out by the method of mathematical simulation using the model of spatial oscillations of the coupling of five cars and a software complex developed by the BRL DSRS of the Dnipropetrovsk National University of Railway Transport named after Academician V. Lazaryan. Initial data for research: movement of gondola car of the model 12-532 with the typical bogies 18-100 with speeds in the range from 50 to $90 \mathrm{~km} / \mathrm{h}$ in the curves with radii 350 and $600 \mathrm{~m}$, with superelevation 130 and $120 \mathrm{~mm}$, correspondingly. The rails P65, wooden sleepers, broken stone ballast [5-8, $16]$.

In this study, the influence of increase of loading from the car axle on the rails during cargo transportation was considered. The graphs of changes of indicators under analysis when moving in the curved track sections of $R=600$ and $350 \mathrm{~m}$ are presented in Fig. 10-13.

As one can see from Fig. $10(a, b)$, in general, with loading increase from the car axle on the rails the vertical dynamics coefficients increase in the whole range of speeds. The $K_{\mathrm{vd}}$ indicators do not exceed the permissible norm both in the curve of $R=600 \mathrm{~m}$ and in the curve of $R=350 \mathrm{~m}$ and correspond to the excellent level of assessment $K_{\mathrm{vd}}=0.5[8]$. 
$a$

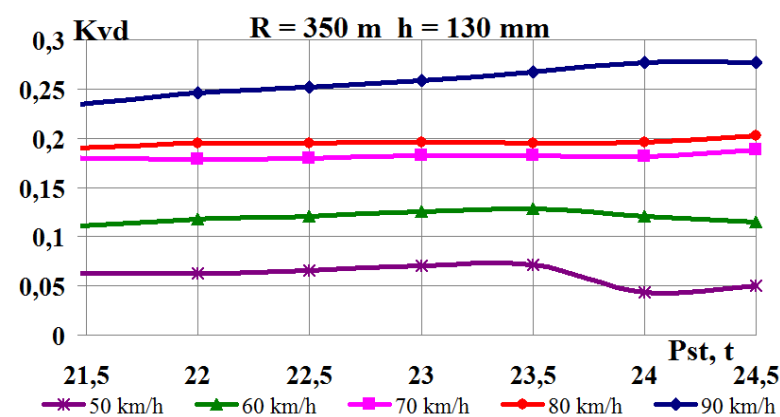

$c$

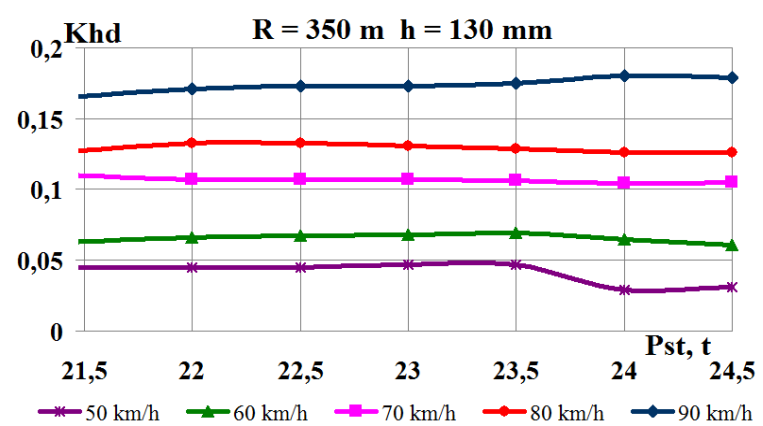

$e$

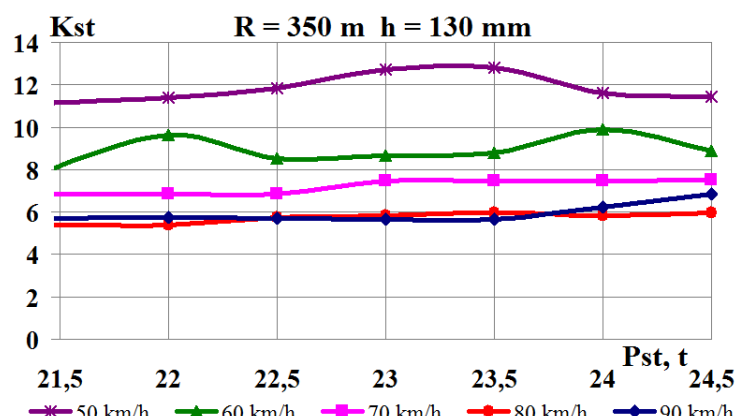

$b$

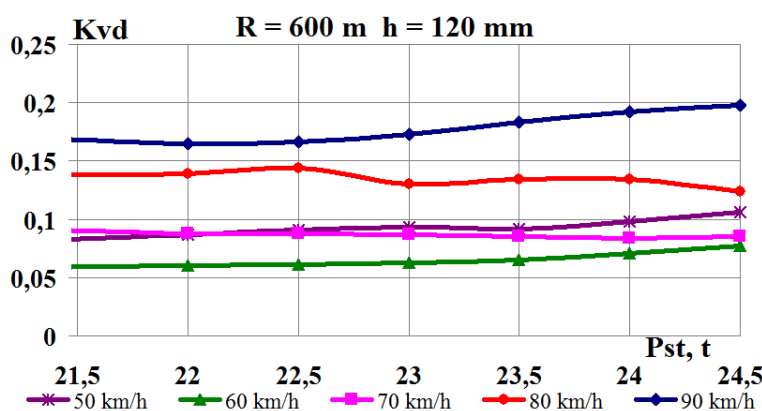

$d$
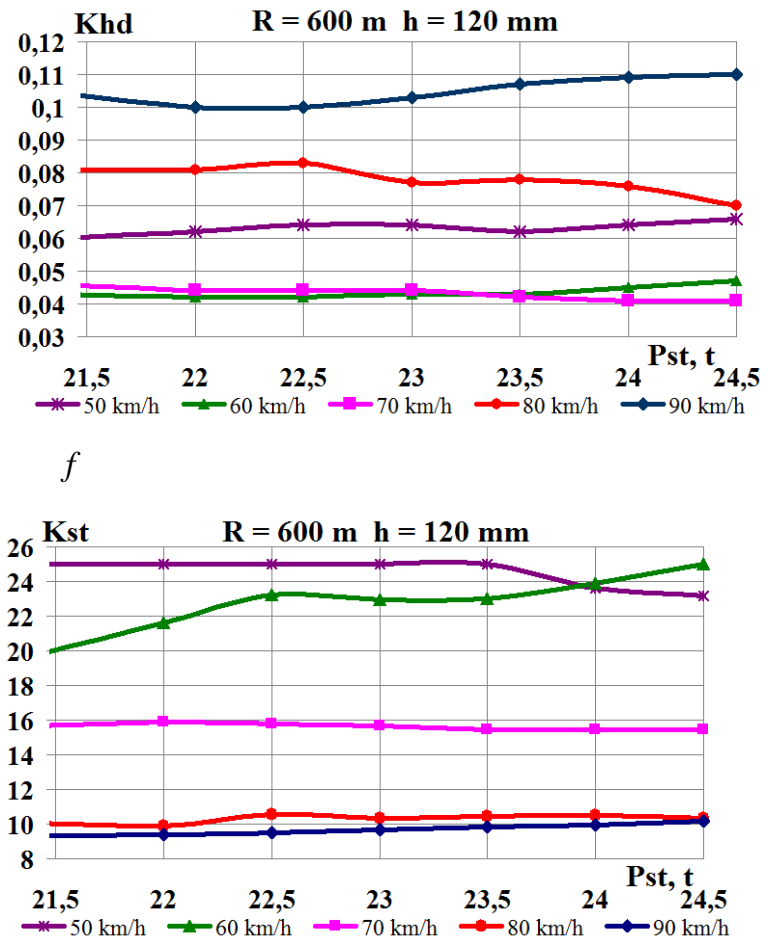

Fig. 10. Dependencde graphs on the axle loading of the car on rails when moving in the corresponding curve: $a, b$-coefficients of vertical dynamics; $c, d$-coefficients of horizontal dynamics;

$e, f$-derailment stability coefficient

Fig. $10(c, d)$, presents the coefficients of horizontal dynamics $K_{\mathrm{hd}}$ when moving in curves with a radius $R=350 \mathrm{~m}$ and $600 \mathrm{~m}$, correspondingly. From these figures, one can see that with loading increase from the car axle on the rails, the coefficients of horizontal dynamics $K_{\mathrm{hd}}$ slightly change and remain in the curves of $R=600$ and $R=350 \mathrm{~m}$ at the excellent level of assessment $K_{\text {hd }}=0.2$ [8].

The derailment stability coefficients in the curves of $R=350$ and $R=600 \mathrm{~m}$ (Fig. 10, $d, e$ ) have little dependence on the loading increase from the car axle on the rails and in both cases do not exceed the minimum permissible value $\left[K_{\mathrm{st}}\right]=1.3$. On the average the value $K_{\mathrm{st}}$ in the curves $R=350 \mathrm{~m}$ is $52.2 \%$ lower than the corresponding values in the curve $R=600 \mathrm{~m}$. From the obtained results, it follows that in case of increase of loading from the car axle on the rails, the movement speed has a significant influence on the car stability in the curved track sections.

Fig. 11 shows the coefficients of vertical $K_{\mathrm{vdt}}$ and horizontal $K_{\text {hdt }}$ dynamics of the track accord- 
ing to the forces of interaction of the wheels and rails, as well as the displacement stability coeffi-

$a$

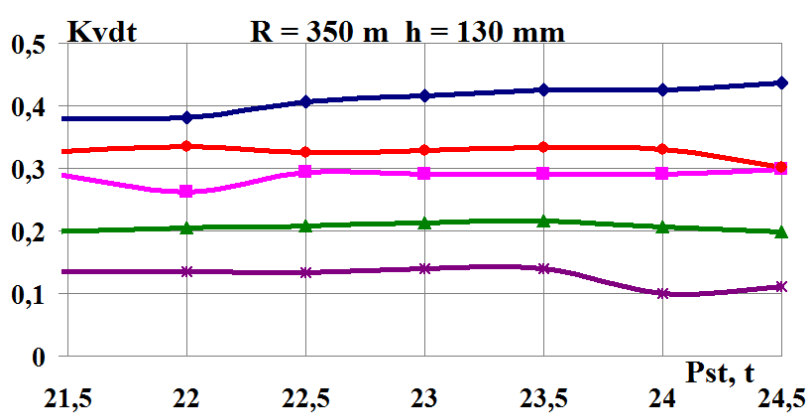
$c$
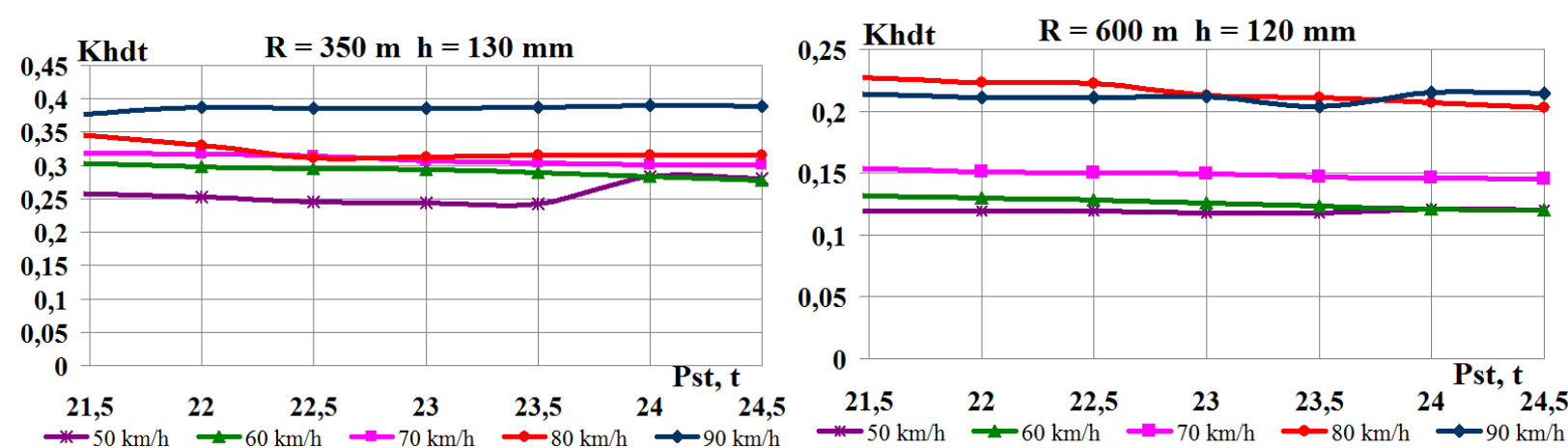

$e$
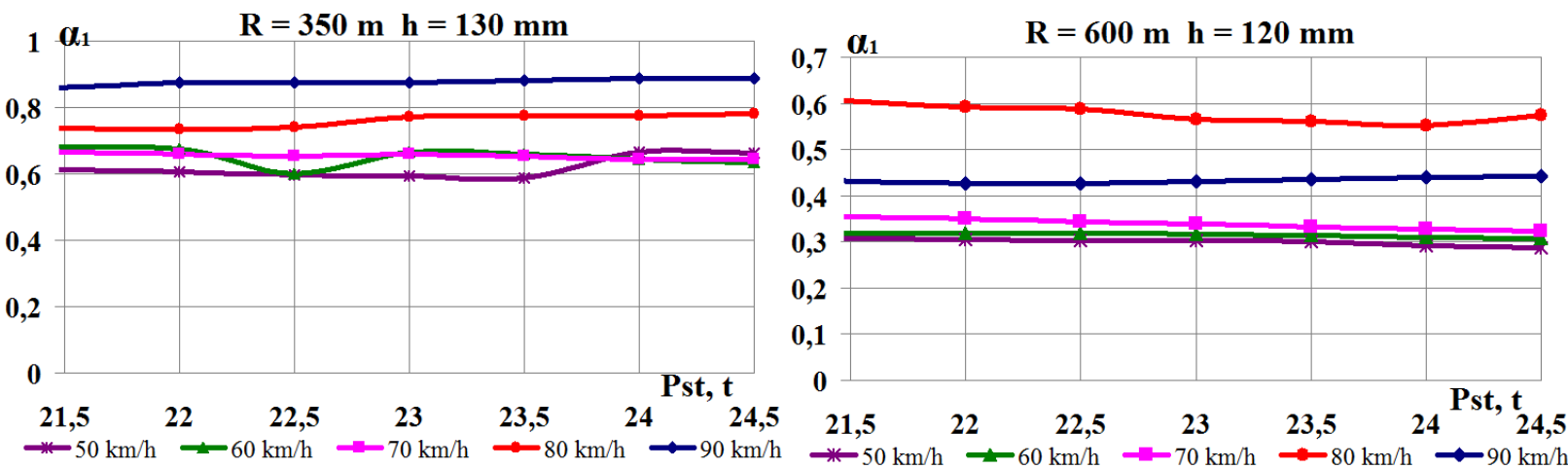

cient $\alpha_{1}$ of the track panel when moving in the corresponding curved track sections.

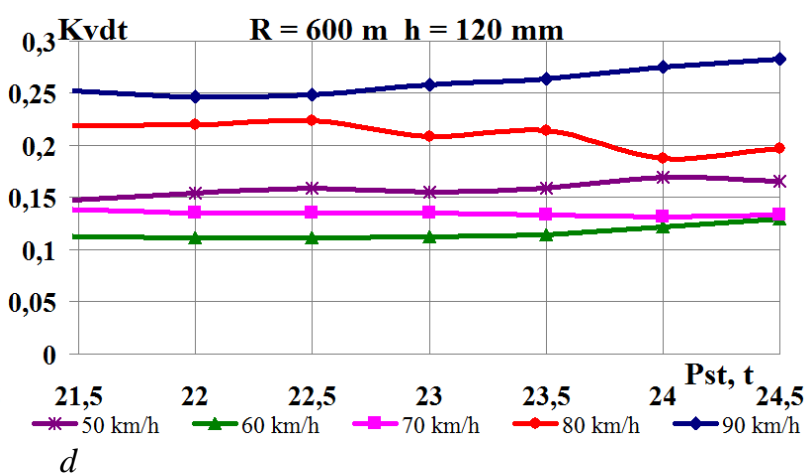

$$
f
$$

Fig. 11. Graphs of dependence on the axle loading of car

on the rails when moving in the corresponding curve:

$a, b$-coefficient of vertical dynamics of the track for the forces of interaction of wheels and rails;

$c, d$-coefficient of horizontal dynamics of the track for the forces of interaction of wheels and rails;

$e, f$-displacement stability coefficient of the track panel

The permissible value of the coefficient of vertical dynamics of the track $K_{\text {vdt }}$ is calculated according to the permissible dynamic load per unit length on the railway track from the group of the bogie axles of $168 \mathrm{kN} / \mathrm{m}$ and is $\left[K_{\mathrm{vdt}}\right]=0.45$ for this type of rolling stock [7]. The coefficient of Creative Commons Attribution 4.0 International doi: $10.15802 / \mathrm{stp} 2019 / 158127$ vertical dynamics of the track $K_{\text {vdt }}$ (Fig. 11, $a, b$ ) does not exceed the permissible value in the curves with radius of $R=350$ and $600 \mathrm{~m}$.

The coefficient of horizontal dynamics of the track $K_{\text {hdt }}$ (Fig. 11, $e, f$ ), which is considered the safety criterion against the track panel displacesafety criterion against the track panel displaceC A. O. Shvets, O. O. Bolotov, 2019 
ment, does not exceed the permissible value $\left[K_{\text {hdt }}\right]=0.4$ in the curves with radius of $R=350$ and $600 \mathrm{~m}$. Only at the speed of $90 \mathrm{~km} / \mathrm{h}$ in the curve of $R=350 \mathrm{~m} K_{\text {hdt }}$ on average has a value of 0.39 and approaches the maximum permissible value.

The value of the stability coefficient of the track panel $\alpha_{1}$ (Fig. 11, c, d) in the track with broken stone ballast is $0.6-0.9$, which is less than the

$a$

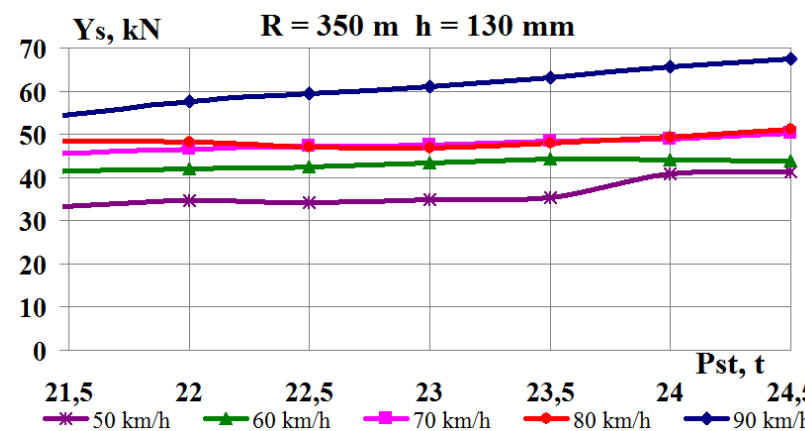

c
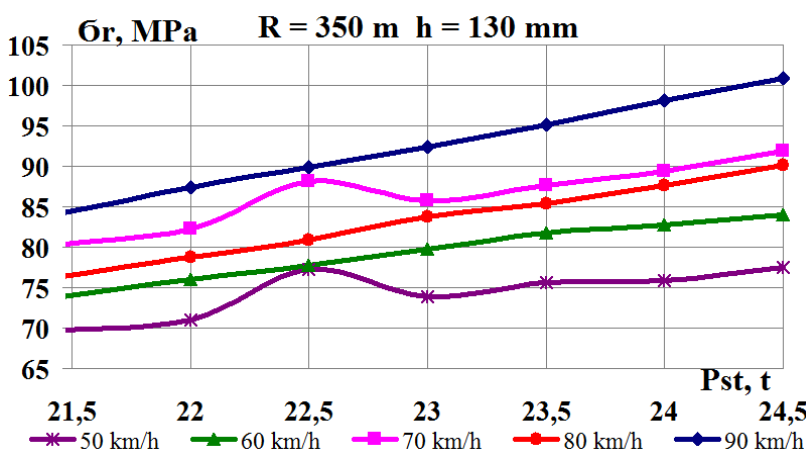

$e$

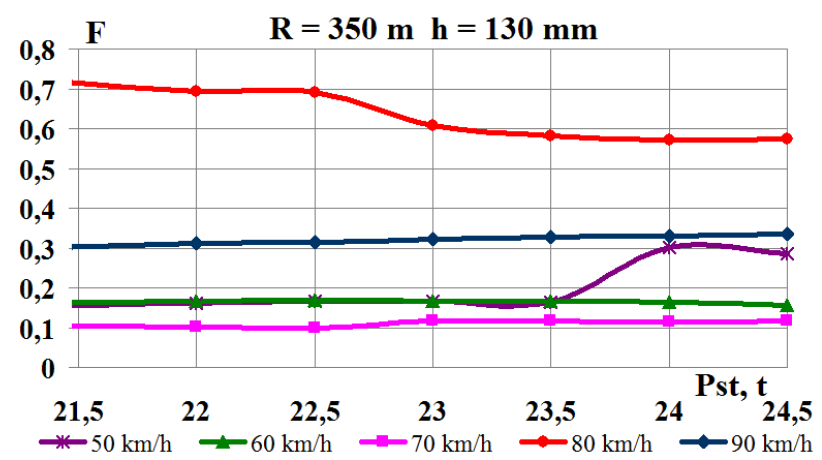

permissible value. Therefore for the track with broken stone ballast at normal movement speeds $(V \leq 120 \mathrm{~km} / \mathrm{h})$ one should take $\left[\alpha_{1}\right]=1.4[5,7]$.

Fig. 12 shows the speed influence on the interaction indicators of track and rolling stock in the curves of $R=350$ and $R=600 \mathrm{~m}$, correspondingly - the side force acting from the track on the wheel, the edge stress at the rail base, the wear factor of the side edge of the wheel tread.

$$
b
$$

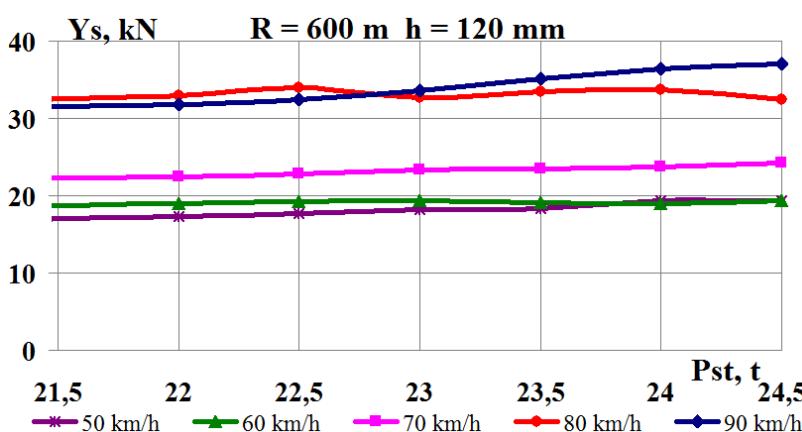

$d$
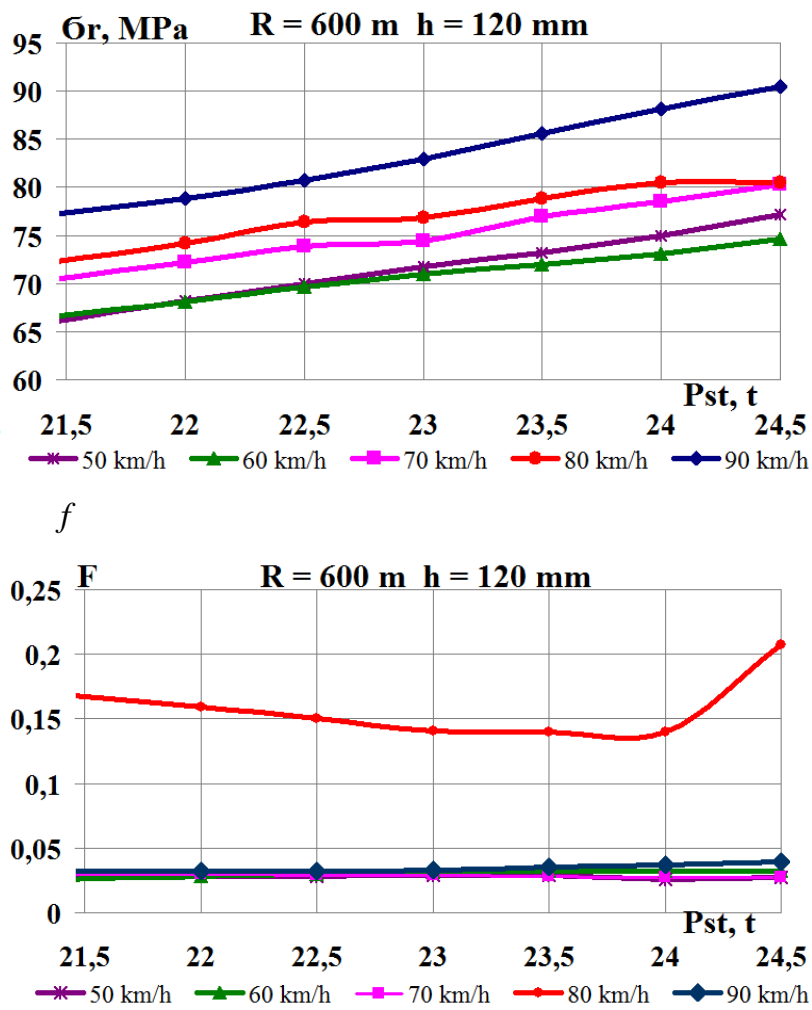

Fig. 12. Graphs of dependence on the axle loading of the car on rails when moving in the corresponding curve: $a, b$-side force acting from the track side on the wheel; $c, d$-edge stress at the rail base; $e, f$ - the wear factor of the side edge of the wheel tread

Creative Commons Attribution 4.0 International doi: $10.15802 / \mathrm{stp} 2019 / 158127$ 
The side forces acting from the track on the wheel (horizontal forces) $Y_{\mathrm{s}}$ (Fig. 12, $a, b$ ) increase and, in comparison with the permissible values of $100 \mathrm{kN}$, have no excess. The values $Y_{\mathrm{s}}$ in the curve of $R=350$ are on the average $46.1 \%$ higher than the corresponding values in the curve of $R=600 \mathrm{~m}$.

The dynamic influence of rolling stock on the track increases with increasing the speeds of train movement, and, as a result, the stresses at the rail base edges increase (Fig. 12, $c, d$ ). The maximum stresses occurring at the edges of the rail bases are used as a criterion for establishing the permissible speeds and should not exceed 215 MPa before the passage of the normative tonnage and $165 \mathrm{MPa}$ after the passage of the normative tonnage for the track with non-heat treated rails P65.

According to the results of calculations, the edge stresses increase with increasing the move-

$a$

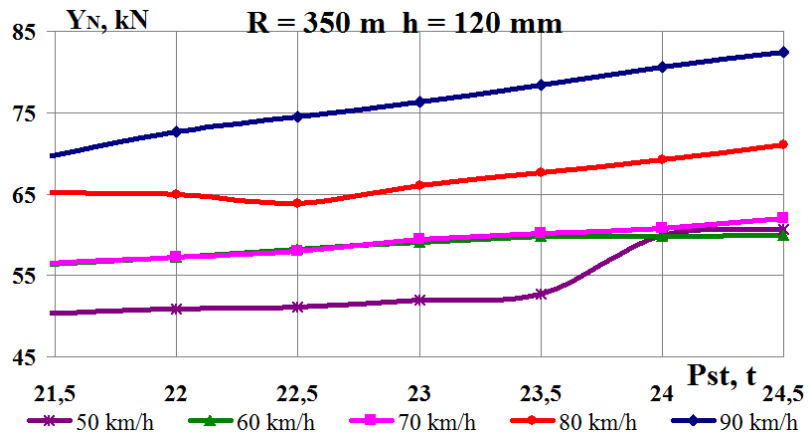

c

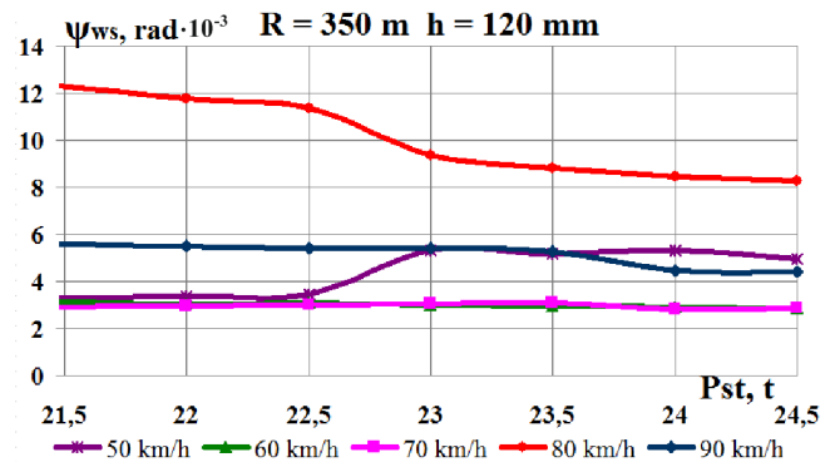

ment speed and do not exceed the permissible values for both types of rails [5, 7].

As the movement speed increases, for example at the speed of $80 \mathrm{~km} / \mathrm{h}$, the wear factor of the side edge of the wheel tread $F$ increases significantly (Fig. 12,e, $f$ ) and in the curve of $R=350 \mathrm{~m}$ it $74.86 \%$ exceeds the corresponding value at $R=600 \mathrm{~m}$. In turn, $F$ increase at the speed of $80 \mathrm{~km} / \mathrm{h}$ in the curve $R=350 \mathrm{~m}$ is $66.2 \%$ as compared with other speed intervals. The same indicator in the curve $R=600 \mathrm{~m}$ is $80.5 \%$.

The wear factor of the side edge of the wheel tread $F$ is determined as a characteristic equal to the product of the guiding force $Y_{\mathrm{N}}$ on the angle of hunting (climbing) $\psi_{\mathrm{ws}}$ of the wheel on the rail. Fig. 13 shows the speed influence on the interaction indicators of rolling stock and track in the curves of $R=350 \mathrm{~m}$ and $R=600 \mathrm{~m}$, correspondingly, guiding force acting on the wheel from the track side on the wheel and the wheel set hunting.

$b$

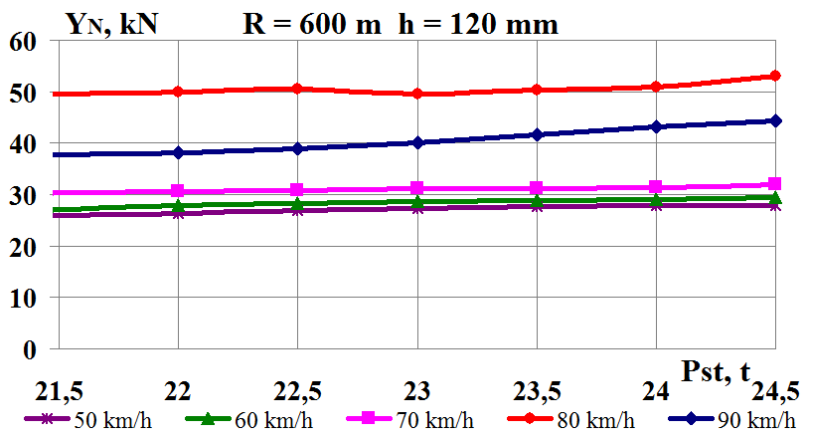

$d$

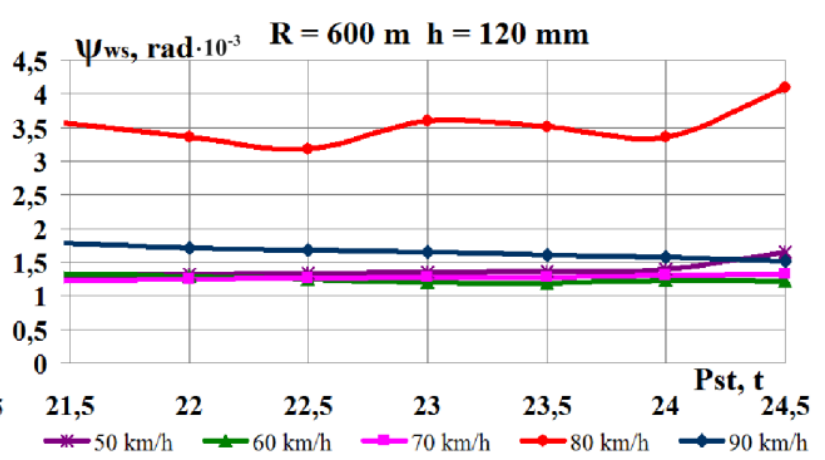

Fig. 13. Graphs of dependence on the axle loading of the car on the rails in the corresponding curve: $a, b$ - guiding force acting from the track side on the wheel; $c, d$-wheel set hunting 
Guiding forces acting on the wheel $Y_{\mathrm{N}}$ from the track (Fig. 13, $a, b$ ), significantly increase in the curve of $R=350 \mathrm{~m}$ with increasing the movement speed. The values $Y_{\mathrm{N}}$ in the curve of $R=350 \mathrm{~m}$ on the average are $43.6 \%$ more than the corresponding values in the curve of $R=600 \mathrm{~m}$.

The results of calculations show (Fig. 13, $c, d$ ) that the hunting angle of the wheel set $\psi_{\text {ws }}$ at the speed of $80 \mathrm{~km} / \mathrm{h}$ in the curves of the small and middle radius is significantly differ from the other range of the investigated speeds. The $\psi_{\mathrm{ws}}$ values in the curve of $R=350 \mathrm{~m}$ on average exceed the corresponding value in the curve of $R=600 \mathrm{~m}$ by $64.9 \%$.

The need to limit the speed of cars on the bogies of the model $18-100$ is due to the loss of movement stability, when the dynamic transverse oscillations of the hunting of the car parts stop damping, becoming steady (self-oscillations). The wheel sets after the loss of movement stability continuously oscillate within the rail gap, while the amplitude of self-oscillations may vary within the rail gap, but no oscillation damping is observed. The side frames of the bogie are subject to autooscillations of the hunting, since the dynamic movements of the wheel sets are violated predominantly in the antiphase. The car body in turn, starts hunting because of antiphase dynamic displacements of the bogies.

As it is known, the safe train movement speed, which include the cars on the serial bogies of the model 18-100, is determined not by the design speed.$V_{\mathrm{d}}$, , but by the critical one $V_{\text {cr }}$, which is unstable. The critical speed $V_{\text {cr }}$ varies according to the following factors [10]:

- the stiffness of the elastic connection between the sidewalls and the wheel sets;

- the car weight - the critical speed of empty cars is lower than that of the loaded ones;

- gravity center of the car - with the increase in the gravity center the critical speed is reduced.

In addition, the critical speed $V_{\text {cr }}$ changes during operation depending on the wear of undercarriages, primarily the wheel rims, and the track plan - when passing the curved track sections, the critical speed is higher compared to the value in the straight track sections. At speeds exceeding the critical one, the car loses movement stability. As a result, there are self-oscillations of the lateral swaying of the wheel sets, the bogies and body hunting. There is increase in the horizontal transverse accelerations and frame forces, which worsens the stability coefficient against derailment (Fig. 10, $e, f$ ).

Thus, the movement speed limitation in the curves of small and medium radius, established by the norms, should be observed. It caused by a sharp decrease in the stability coefficient against derailment and increase in the wear factor of the lateral edge of the wheel tread.

\section{Originality and practical value}

Originality of the work lies in the study of the influence of increasing the axle loading in gondola cars on their dynamic parameters and interaction indicators of the tracks and rolling stock in order to solve the problem of predicting the rolling stock dynamics and includes the results of theoretical studies taking into account the movement speed in the curved track sections of the small and medium radius.

The obtained results have a practical orientation. During the theoretical studies and after the simulation, taking into account the oscillation processes of the freight car and cargo with increase in the gondola axle loading, dependences of the main dynamic parameters taking into account the movement speed are obtained. Application of the results will increase the traffic safety of freight cars and will improve the technical and economic performance of railway transport.

\section{Conclusions}

The article presents analysis of theoretical studies of dynamic qualities of rolling stock on the example of gondola cars, calculations are made using the package of applied programs.

Based on the theoretical study, the following conclusions can be made:

- the movement speed limitation in the curves of the small and medium radius is caused by a decrease in the level of the derailment stability coefficient and increase in the wear factor of the side edges of the wheel tread and should not exceed the values determined by the norms; 
- the calculations have shown the need to limit the movement speed in the curves of medium radius to $70 \mathrm{~km} / \mathrm{h}$, due to the fact that the average weighted speed of trains of $80 \mathrm{~km} / \mathrm{h}$ is critical for the gondolas on the bogies of the model 18-100, which leads to the loss of stability and increase in the wear factor of the side edge of the wheel tread;
- axle loading increase will increase failure rate of the rails due to defects of contact-fatigue nature, deterioration of the track condition, artificial structures, and the roadbed, which in turn will cause the movement speed limitation of passenger and freight trains, as well as more intense failure of elements of the track superstructure and increase in the annual operating costs.

\section{LIST OF REFERENCE LINKS}

1. Автоматизированная система дозированной погрузки щебня в вагоны [Electronic resource]. - Available at: https://clck.ru/F7bWE - Title from the screen. - Accessed : 30.01.2019.

2. Аппаратно-программный комплекс контроля загрузки вагонов «АРСИС.Сканер» [Electronic resource] // ООО «Малленом Системс». - Available at: http://www.mallenom.ru/Docs/ARSCIS.Scanner.pdf - Title from the screen. - Accessed : 30.01.2019.

3. Вагонний парк ПАТ «Укрзалізниця» та взаємодія з приватними власниками рухомого складу / Департамент розвитку і технічної політики (ЦТЕХ) ; кер. ПАТ «Укрзалізниця». - Харків, 2017. - 11 с.

4. Вагонные весы [Electronic resource] // Точное Определение Массы (ТОМ). - Available at: http://tom.odessa.ua/index.php?p=vagon - Title from the screen. - Accessed : 28.01.2019.

5. Даніленко, Е. І. Залізнична колія : підруч. для вищ. навч. закл. : у 2 т. / Е. І. Даніленко. - Київ : Інпрес, 2010. - T. 2. -456 c.

6. Данович, В. Д. Математическая модель пространственных колебаний сцепа пяти вагонов, движущихся по прямолинейному участку пути / В. Д. Данович, А. А. Малышева // Транспорт. Нагруженность и прочность подвижного состава : сб. науч. тр. / Днепропетр. гос. техн. ун-т ж.-д. трансп. - Днепропетровск, 1998. - С. 62-69.

7. ДСТУ 7571:2014. Рухомий склад залізниць. Норми допустимого впливу на залізничну колію 1520 мм. Введ. 2014-02-12. - Київ : УкрНДНЦ, 2014. - 33 с.

8. ДСТУ ГОСТ 33211:2017. Вагони вантажні. Вимоги до міцності та динамічних якостей (ГОСТ 33211 2014). - Введ. 2017-07-01. - Київ : УкрНДНЦ, 2017. - 58 с.

9. Засоби для механізації розрівнювання насипних вантажів у напіввагонах / С. В. Романович, Г. М. Афанасов, Л. М. Козар, В. В. Бут // Зб. наук. пр. Укр. держ. акад. залізн. трансп. - Харків, 2014. Вип. 148 (1). - С. 116-121.

10. Лазарян, В. А. Устойчивость движения рельсовых экипажей / В. А. Лазарян, Л. А. Длугач, М. Л. Коротенко. - Киев : Наукова думка, 1972. - 197 с.

11. Определение допустимых сил при оценке устойчивости грузовых вагонов от выжимания в поездах / А. А. Швец, К. И. Железнов, А. С. Акулов, А. Н. Заболотный, Е. В. Чабанюк // Наука та прогрес транспорту. - 2016. - № 1 (61). - С. 189-192. doi: 10.15802/stp2016/61045

12. Правила перевезення вантажів навалом і насипом (ст. 37 Статуту) [Electronic resource] : затв. Наказом М-ва транспорту та зв’язку України від 20.08.2001 р. № 542 // Законодавство України. - 2014. - Available at: http://zakon.rada.gov.ua/laws/show/z0795-01 - Title from the screen. - Accessed : 28.01.2019.

13. Правила перевезення вантажів у вагонах відкритого типу (ст. 32 Статуту) [Electronic resource] : затв. Наказом М-ва транспорту та зв’язку України від 20.08.2001 р. № 542 // Законодавство України. - 2014. - Available at: http://zakon.rada.gov.ua/laws/show/z0796-01 - Title from the screen. - Accessed : 28.01.2019.

14. Рибкін, В. В. Проведення випробувань з впливу на колію та стрілочні переводи рухомого складу нового покоління з осьовим навантаженням 25 т на вісь / В. В. Рибкін, В. С. Савлук // Зб. наук. пр. Укр. держ. акад. залізн. трансп. - Харків, 2012. - Вип. 130. - С. 127-131.

15. Транспортно-разгрузочное оборудование [Electronic resource] // Предприятие Днепротяжмаш. - Аvailable at: http://www.dts.dp.ua/ru/factories/dnieprotiazhmash/products/transportno-razghruzochnoieoborudovaniie - Title from the screen. - Accessed : 28.01.2019.

16. Швець, А. О. Вплив поздовжнього та поперечного зміщення центру ваги вантажу в піввагонах на їх динамічні показники / А. О. Швець // Наука та прогрес транспорту. - 2018. - № 5 (77). - С. 115-128. doi: $10.15802 /$ stp2018/146432 
17. Швець, А. О. Особливості визначення моментів інерції кузовів вантажних вагонів / А. О. Швець // Вісник сертифікації залізничного транспорту. - 2018. - № 5 (51). - С. 20-34.

18. Determination of the issue concerning the lift resistance factor of lightweight car / A. O. Shvets, K. I. Zhelieznov, A. S. Akulov, O. M. Zabolotnyi, Ye. V. Chabaniuk // Наука та прогрес транспорту. - 2015. № 6 (60). - C. 134-148. doi: 10.15802/stp2015/57098

19. Effect of fracture toughness on vertical split rim failure in railway wheels / T. Kato, Y. Yamamoto, H. Kato, S. Dedmon, J. Pilch // Engineering Fracture Mechanics. - 2017. - Vol. 186. - P. 255-267. doi: 10.1016/j.engfracmech.2017.09.025

20. Fatigue behavior and microstructural characterization of a high strength steel for welded railway rails / R. Baptista, T. Santos, J. Marques, M. Guedes, V. Infante // International Journal of Fatigue. - 2018. - Vol. 117. P. 1-8. doi: 10.1016/j.ijfatigue.2018.07.032

21. Kurhan, D. Determination of Load for Quasi-static Calculations of Railway Track Stress-strain State / D. Kurhan // Acta Technica Jaurinensis. - 2016. - Vol. 9. - Iss. 1. - P. 83-96. doi: 10.14513/actatechjaur.v9.n1.400

22. Nikas, D. Evaluation of local strength via microstructural quantification in a pearlitic rail steel deformed by simultaneous compression and torsion / D. Nikas, X. Zhang, J. Ahlström // Materials Science and Engineering: A. - 2018. - Vol. 737. - P. 341-347. doi: 10.1016/j.msea.2018.09.067

\title{
А. О. ШВЕЦЬ ${ }^{1 *}$, О. О. БОЛОТОВ ${ }^{2 *}$
}

\author{
1*Каф. «Теоретична та будівельна механіка», Дніпровський національний університет залізничного транспорту імені \\ академіка В. Лазаряна, вул. Лазаряна, 2, Дніпро, Україна, 49010, тел. +38 (050) 21414 19, \\ ел. пошта angela_Shvets@ua.fm, ORCID 0000-0002-8469-3902 \\ ${ }^{2 *}$ ГНДЛ ДМРС, Дніпровський національний університет залізничного транспорту імені академіка В. Лазаряна, \\ вул. Лазаряна, 2, Дніпро, Україна, 49010, тел. +38 (097) 97757 08, ел. пошта bolaks@i.ua, ORCID 0000-0002-0807-0340
}

\section{ВПЛИВ НАВАНТАЖЕННЯ ВІД ОСІ ПІВВАГОНА НА ЙОГО ДИНАМІЧНІ ПОКАЗНИКИ ТА ЗАЛІЗНИЧНУ КОЛІЮ}

Мета. Підвищення максимального навантаження від осі вагона на рейки під час перевезення вантажів і збільшення швидкості руху залізничних екіпажів дозволить посилити інтеграційні процеси між країнами. Для гарантування безпечного й надійного сполучення на залізницях необхідно вдосконалювати контроль, кількісну оцінку динамічної завантаженості рухомого складу, що в процесі його експлуатації складає актуальну науково-технічну задачу. Метою цієї роботи є дослідження впливу збільшення осьового навантаження в піввагонах, з урахуванням можливого підвищення швидкості руху, на їх основні динамічні показники та показники взаємодії рухомого складу з колією. Методика. Дослідження проведене методом математичного й комп'ютерного моделювання динамічної завантаженості піввагона з використанням моделі просторових коливань зчепу п’яти вагонів і програмного комплексу, розробленого в галузевій науково-дослідній лабораторії динаміки й міцності рухомого складу (ГНДЛ ДМРС). Вихідні дані для дослідження: рух піввагона моделі 12-532 з типовими візками 18-100 зі швидкостями в діапазоні від 50 до 90 км/год в кривих радіусами 350 і 600 м, із підвищеннями зовнішньої рейки 130 та 120 мм відповідно. Результати. У статті проаналізовано динамічні якості рухомого складу на прикладі піввагонів; розрахунки виконано з використанням пакета прикладних програм з достатньою для практики точністю. У ході теоретичних досліджень і моделювання з урахуванням процесів коливання вантажного вагона в разі збільшення осьового навантаження отримано залежності основних динамічних показників від швидкості руху. Наукова новизна роботи полягає в дослідженні впливу збільшення осьового навантаження в піввагонах з урахуванням можливого підвищення швидкості руху на ї динамічну завантаженість із метою вирішення задачі прогнозування динаміки рухомого складу. Уперше отримано результати теоретичних досліджень 3 урахуванням швидкості руху в кривих ділянках колії малого та середнього радіуса. Практична значимість. Застосування цих результатів сприятиме підвищенню безпеки руху вантажних вагонів і дозволить поліпшити техніко-економічні показники роботи залізничного транспорту.

Ключові слова: вантаж; піввагони; динамічні показники; криві ділянки колії; осьове навантаження; показники взаємодії; рухомий склад і колія; центр ваги; швидкість руху 


\title{
А. А. ШВЕЦ ${ }^{1 *}$ А. А. БОЛОТОВ ${ }^{2 *}$
}

\author{
1*Каф. «Теоретическая и строительная механика», Днипровский национальный университет железнодорожного транс- \\ порта имени академика В. Лазаряна, ул. Лазаряна, 2, Днипро, Украина, 49010, тел. +38 (050) 2141419 , \\ эл. почта angela_Shvets@ua.fm, ORCID 0000-0002-8469-3902 \\ $2^{*}$ ОНИЛ ДППС, Днипровский национальный университет железнодорожного транспорта имени академика \\ B. Лазаряна, ул. Лазаряна, 2, Днипро, Украина, 49010, тел. +38 (097) 977 57 08, эл. почта bolaks@i.ua, \\ ORCID 0000-0002-0807-0340
}

\section{ВЛИЯНИЕ НАГРУЗКИ ОТ ОСИ ПОЛУВАГОНА НА ЕГО ДИНАМИЧЕСКИЕ ПОКАЗАТЕЛИ И ЖЕЛЕЗНОДОРОЖНЫЙ ПУТЬ}

Цель. Повышение максимальной нагрузки от оси вагона на рельсы при перевозке грузов и увеличение скорости движения железнодорожных экипажей позволит усилить интеграционные процессы между странами. Для обеспечения безопасного и надежного сообщения на железных дорогах необходимо совершенствовать контроль, количественную оценку динамической загруженности подвижного состава, что в процессе его эксплуатации составляет актуальную научно-техническую задачу. Целью данной работы является исследование влияния увеличения осевой нагрузки в полувагонах, с учетом возможного повышения скорости движения, на их основные динамические показатели и показатели взаимодействия подвижного состава с колеей. Методика. Исследование проведено методом математического и компьютерного моделирования динамической загруженности полувагона с использованием модели пространственных колебаний сцепа пяти вагонов и программного комплекса, разработанного в отраслевой научно-исследовательской лаборатории динамики и прочности подвижного состава (ОНИЛ ДППС). Исходные данные исследования: движение полувагона модели 12-532 с типичными тележками 18-100 со скоростями в диапазоне от 50 до 90 км/ч в кривых радиусами 350 и 600 м, с повышениями наружного рельса 130 и 120 мм соответственно. Результаты. В статье проанализированы динамические качества подвижного состава на примере полувагонов; расчеты выполнены с использованием пакета прикладных программ с достаточной для практики точностью. В ходе теоретических исследований и моделирования с учетом процессов колебания грузового вагона при увеличении осевой нагрузки получены зависимости основных динамических показателей от скорости движения. Научная новизна состоит в исследовании влияния увеличения осевой нагрузки в полувагонах с учетом возможного повышения скорости движения на их динамическую нагрузку с целью решения задачи прогнозирования динамики подвижного состава. Впервые представлены результаты теоретических исследований с учетом скорости движения по кривым участкам пути малого и среднего радиуса. Практическая значимость. Применение полученных результатов будет способствовать повышению безопасности движения грузовых вагонов и позволит улучшить технико-экономические показатели работы железнодорожного транспорта.

Ключевые слова: груз; полувагоны; динамические показатели; кривые участки пути; осевая нагрузка; показатели взаимодействия; подвижной состав и колея; центр тяжести; скорость движения

\section{REFERENCES}

1. Avtomatizirovannaya sistema dozirovannoy pogruzki shchebnya v vagony. Retrieved from https://clck.ru/F7bWE (in Russian)

2. Apparatno-programmnyy kompleks kontrolya zagruzki vagonov «ARSIS.Skaner». OOO «Mallenom Sistems». Retrieved from http://www.mallenom.ru/Docs/ARSCIS.Scanner.pdf (in Russian)

3. Vagonnyj park PAT «Ukrzaliznycja» ta vzajemodija z pryvatnymy vlasnykamy ruhomogo skladu. (2017). Kharkiv: Department of Development and Technical Policy; manager PJSC «Ukrzaliznytsya». (in Ukrainian)

4. Vagonnye vesy. Tochnoe Opredelenie Massy (TOM). Retrieved from http://tom.odessa.ua/index.php?p=vagon (in Russian)

5. Danilenko, E. I. (2010). Zaliznychna koliia: pidruchnyk dlia vyshchykh navchalnykh zakladiv. (Vol. 1-2). Kyiv: Inpres. (in Ukrainian)

6. Danovich, V. D., \& Malysheva, A. A. (1998). Mathematical Model of Spatial Oscillations of the Coupling of Five Cars Moving Along a Rectilinear Section of the Track. Transport. Stress Loading and Durability of a Rolling Stock (pp. 62-69). Dnepropetrovsk. (in Russian) 
7. Rukhomyj sklad zaliznycj. Normy dopustymogho vplyvu na zaliznychnu koliju $1520 \mathrm{~mm}$. 33 DSTU 7571:2014 (2014). (in Ukrainian)

8. Vahony vantazhni. Vymohy do mitsnosti ta dynamichnykh yakostei, 58 DSTU 33211:2017 (2017). (in Ukrainian)

9. Romanovych, Y. V., Afanasov, H. M., Kozar, L. M., \& But, V. V. (2014). Zasoby dlia mekhanizatsii rozrivniuvannia nasypnykh vantazhiv u napivvahonakh. Collected Scientific Works of Ukrainian State University of Railway Transport, 148(1), 116-121. (in Ukrainian)

10. Lazaryan, V. A., Dlugach, L. A., \& Korotenko, M. L. (1972). Ustoychivost dvizheniya relsovykh ekipazhey. Kiev: Naukova dumka. (in Russian)

11. Shvets, A. O., Zhelieznov, K. I., Akulov, A. S., Zabolotnyi, O. M., \& Chabaniuk, E. V. (2016). Determination the permissible forces in assessing the lift resistant factor of freight cars in trains. Science and Transport Progress, 1(61), 180-192. doi: 10.15802/stp2016/61045 (in Russian)

12. Pravyla perevezennia vantazhiv navalom i nasypom (2014). Retrieved from http://zakon.rada.gov.ua/laws/show/z0795-01 (in Ukrainian)

13. Pravyla perevezennia vantazhiv u vahonakh vidkrytoho typu (2014). Retrieved from http://zakon.rada.gov.ua/laws/show/z0796-01 (in Ukrainian)

14. Rybkin, V. V., \& Savluk, V. Y. (2012). Provedennia vyprobuvan z vplyvu na koliiu ta strilochni perevody rukhomoho skladu novoho pokolinnia z osovym navantazhenniam $25 \mathrm{t}$ na vis. Collected Scientific Works of Ukrainian State University of Railway Transport, 130, 127-131. (in Ukrainian)

15. Transportno-razgruzochnoe oborudovanie. Predpriyatie Dneprotyazhmash. Retrieved from http://www.dts.dp.ua/ru/factories/dnieprotiazhmash/products/transportno-razghruzochnoie-oborudovaniie (in Russian)

16. Shvets, A. O. (2018). Influence of the longitudinal and transverse displacement of the center of gravity of the load in gondola cars on their dynamic indicators. Science and Transport Progress, 5(77), 115-128. doi: $10.15802 /$ stp2018/146432 (in Ukrainian)

17. Shvets, A. O. (2018). Specifics of Determining the Moments of Inertia a Freight Wagons Bodies. Visnyk sertyfikatsii zaliznychnoho transportu, 5(51), 20-34. (in Ukrainian)

18. Shvets, A. O., Zhelieznov, K. I., Akulov, A. S., Zabolotnyi, O. M., \& Chabaniuk, Y. V. (2015). Determination of the issue concerning the lift resistance factor of lightweight car. Science and Transport Progress, 6(60), 134-148. doi: 10.15802/stp2015/57098 (in English)

19. Kato, T., Yamamoto, Y., Kato, H., Dedmon, S., \& Pilch, J. (2017). Effect of fracture toughness on vertical split rim failure in railway wheels. Engineering Fracture Mechanics, 186, 255-267. doi: 10.1016/j.engfracmech.2017.09.025 (in English)

20. Baptista, R., Santos, T., Marques, J., Guedes, M., \& Infante, V. (2018). Fatigue behavior and microstructural characterization of a high strength steel for welded railway rails. International Journal of Fatigue, 117, 1-8. doi: 10.1016/j.ijfatigue.2018.07.032 (in English)

21. Kurhan, D. (2016). Determination of Load for Quasi-static Calculations of Railway Track Stress-strain State. Acta Technica Jaurinensis, 9(1), 83-96. doi: 10.14513/actatechjaur.v9.n1.400 (in English)

22. Nikas, D., Zhang, X., \& Ahlström, J. (2018). Evaluation of local strength via microstructural quantification in a pearlitic rail steel deformed by simultaneous compression and torsion. Materials Science and Engineering: A, 737, 341-347. doi: 10.1016/j.msea.2018.09.067 (in English)

Received: Sep. 10, 2018

Accepted: Jan. 18, 2019 